Sains Malaysiana 50(2)(2021): 395-407

http://dx.doi.org/10.17576/jsm-2021-5002-11

\title{
Physiochemical and in vitro Cytotoxicity Properties of Biocompatible Palm Fatty Acid-Based Polyesters
}

(Sifat Fizikokimia dan Kesitotoksikan in vitro Poliester Bioserasi Berasaskan Asid Lemak Sawit)

\author{
Yvonne Tze Qzian Ling, Ying Jye Yap, Yi Xin Heng, Siang Yin LeE*, Rhun Yian Koh, Desmond Teck \\ Chye Ang, Chin Hua Chia \& Seng NeOn Gan
}

\section{ABSTRACT}

With the sharp rise in global interest in sustainability and environmental concerns, there is a growing demand in replacing petroleum-derived raw materials with renewable plant-based raw materials in the production of polymers. In this study, two palm fatty acid polyesters were synthesized from palmitic and stearic acids. Their chemical structures were identified by FTIR and ${ }^{1} H$-NMR analysis. Both polyesters showed a moderately high conversion rate from the acid value determination. DSC analysis showed that the palmitic acid polyester (PAP) had a lower $T_{g}$ than that of stearic acid polyester (SAP), where PAP had a $T_{g}$ of $1.8{ }^{\circ} \mathrm{C}$, while SAP had a $T_{g}$ of $31.9{ }^{\circ} \mathrm{C}$. TGA demonstrated that thermal decomposition of both polyesters took place via two-stage processes, which occurred above $200{ }^{\circ} \mathrm{C} . G P C$ analysis showed that PAP $(1031 \mathrm{~g} / \mathrm{mol})$ had a higher $M_{n}$ value than SAP $(972 \mathrm{~g} / \mathrm{mol})$. MTT assays were performed to determine the cytotoxicity of these polyesters against human keratinocytes (HaCaT), mouse fibroblasts (3T3), mouse hepatocytes (H2.35), and canine kidney cells (MDCK) in both dose- and time-dependent manners, with SDS serving as the experimental benchmark. Comparative cytotoxicity test showed that both PAP and SAP were biocompatibility and non-cytotoxic with the cell viability well above 80\%, except SAP demonstrated a moderately low cytotoxicity on fibroblasts with cell viability remaining as 50.4\% following $72 \mathrm{~h}$ exposure at $100 \mu \mathrm{g} / \mathrm{mL}$ of concentration. These findings suggest that the natural-sourced palm fatty acid polyesters have high potential to be used in pharmaceutical and nutraceutical applications.

Keywords: Bio-based; cytotoxicity; palm fatty acid; polyester

\section{ABSTRAK}

Dengan kenaikan mendadak minat secara global terhadap kelestarian dan kebimbangan alam sekitar, terdapat permintaan yang semakin meningkat untuk menggantikan bahan mentah berasaskan petroleum kepada bahan mentah berasaskan tumbuhan yang boleh diperbaharui untuk penghasilan polimer. Dalam kajian ini, dua poliester berasaskan asid lemak sawit telah disintesis daripada asid palmitik dan stearik. Struktur kimia kedua-dua poliester telah dikenal pasti oleh analisis FTIR dan ${ }^{1} H$-NMR. Daripada ujian penentuan nilai asid, kedua-dua poliester menunjukkan kadar penukaran yang agak tinggi. Analisis DSC juga menunjukkan poliester asid palmitik(PAP) mempunyai $T_{g}$ yang lebih rendah daripada poliester asid stearik (SAP) dengan PAP mempunyai $T_{g} 1.8^{\circ} \mathrm{C}$ dan SAP mempunyai $T_{g} 31.9^{\circ} \mathrm{C}$. Analisis TGA menunjukkan terdapat dua peringkat penguraian terma poliester yang bermula dari $200{ }^{\circ} \mathrm{g} k e$ atas. Analisis GPC menunjukkan bahawa PAP (1031 g/mol) mempunyai nilai Mn yang lebih tinggi daripada SAP (972 g/ mol). Ujian MTT dilakukan untuk menentukan kesitotoksikan poliester terhadap kultur sel seperti keratinosit manusia (HaCaT), tikus fibroblas (3T3), hepatosit tetikus (H2.35) dan sel ginjal kanin (MDCK) dalam kedua-dua faktor dos dan masa. SDS berfungsi sebagai penanda aras uji kaji untuk perbandingan. Hasil kajian menunjukkan bahawa PAP and SAP mempunyai daya tahan sel melebihi $80 \%$ dan bersifat bioserasi serta tidak sitotoksik, kecuali SAP menunjukkan sitotoksik sederhana rendah dengan daya tahan sel 50.4\% ekoran pendedahan sel selama 72 jam pada kepekatan 100 $\mu \mathrm{g} / \mathrm{mL}$. Keputusan kajian ini mencadangkan bahawa poliester berasaskan asid lemak sawit mempunyai potensi tinggi untuk digunakan dalam aplikasi farmaseutik dan nutraseutik.

Kata kunci: Asid lemak sawit; berasaskan biologi; kesitotoksikan; poliester 


\section{INTRODUCTION}

From the past, many polymers were commercially produced from petroleum-based materials. However, price and supply fluctuations of petroleum-based raw materials along with stringent government regulations are the major restraints inhibiting the market growth of these finite raw materials. This has encouraged the use of natural or bio-based derived raw materials for the development of polymeric products. Bio-based polymers derived from the plants are highly favorable due to their cheap, infinite renewable sources, more biodegradable and ecological compatibility compared to petroleum-based polymers (Garrison et al. 2016). Thus, bio-based polymers have gained a worldwide interest for their positive impacts towards environment and climate change whilst meeting market demands (Babu et al. 2013). The use of sustainable materials, particularly generated from natural plants, would lead to a significant reduction in greenhouse gas emissions and carbon footprint during the production of bio-based polymers (De et al. 2015).

Vegetable oil is one of the widely used starting materials in synthesizing bio-based polymers due to its non-exhaustible and renewable resources, whereby palm oil is the main interest of this study due to its high abundant and easily available in Malaysia. In facts, fatty acids are the main components in the palm oil. They exist as aliphatic long chain carboxylic acids available either in saturated or unsaturated form. Palm oil consists of almost equal amount of saturated $(45.3 \mathrm{~g} / 100 \mathrm{~g})$ and unsaturated $(49.9 \mathrm{~g} / 100 \mathrm{~g})$ fatty acids. Generally, there are more studies reported about the usage of unsaturated fatty acids in polymer synthesis for various applications (Ang \& Gan 2012; Lee et al. 2010; Lee \& Gan 2013). Nevertheless, polymer synthesis using saturated fatty acid is less in examined due to its limited reactive functionality.

Recently, in vitro methods, particularly cell lines have been used extensively to detect the toxicity of polymers at the cellular level (Bakand et al. 2006, 2005; Hoh \& Maier 1993; Lee at al. 2000). 3-(4,5-dimethylthiazol-2yl)-2,5 diphenyl tetrazolium bromide (MTT) assay is generally applied for the quantitative measurement of the cell cytotoxicity, viability and proliferation as it is a reliable indicator of the cell metabolic activity. This colorimetric assay measures the capacity of mitochondrial dehydrogenase enzymes in living cells by the reduction of a yellow, water-soluble tetrazolium salt, MTT, into a water-insoluble dark blue formazan via the cleavage of the tetrazolium ring. The relative toxicity compared to controls was assessed from the amount of formazan produced which is directly proportional to the viable cell number and inversely proportional to the degree of cytotoxicity (Riss et al. 2016).
The present work describes the synthesis of palm fatty acid polyesters from natural-sourced materials and their physiochemical properties were subsequently determined. The cytotoxicity of the polyesters was evaluated via MTT assay towards four cell lines of keratinocytes, fibroblasts, hepatocytes, and kidney cells. This preliminary biocompatibility results will justify the potential of these polyesters in topical, pharmaceutical and nutraceutical applications.

\section{MATERIALS AND METHODS}

\section{MATERIALS}

Palmitic acid (PA) was a kind gift from Southern Acids Industries Sdn. Bhd., Klang, Malaysia; whereas, stearic acid (SA) was gifted by Moi Foods Malaysia Sdn. Bhd. Dimethylolpropionic acid (DMPA), sodium dodecyl sulfate (SDS), glycerol, toluene, potassium hydrogen phthalate, phenolphthalein, ethanol, sodium hydroxide, and potassium hydroxide were purchased from Merck Sdn. Bhd., Selangor, Malaysia. Cell lines of HaCaT human keratinocytes, (ATCC ® PCS-200-010 NIH/3T3 mouse fibroblasts (ATCC ${ }^{\circledR}$ CRL1658 ${ }^{\mathrm{TM}}$ ), H2.35 mouse hepatocytes (ATCC ${ }^{\circledR}$ CRL-1995 ${ }^{\mathrm{TM}}$ ) and canine kidney cells MDCK (NBL-2) (ATCC® CCL-34 ${ }^{\mathrm{TM}}$ ) were purchased from the American Type Culture Collection (ATCC), Manassas, USA. The tetrazolium dye, MTT, was purchased from Biobasic, Markham, Canada. Fetal bovine serum (FBS) and dimethyl sulfoxide were supplied by Sigma-Aldrich Sdn. Bhd., Selangor, Malaysia. Dulbecco's Modified Eagle's medium (DMEM) was purchased from Gibco, Gran Island, New York, USA. All chemicals were reagent grade and used without further purification.

\section{SYNTHESIS OF PALM FATTY ACID POLYESTERS}

The palm fatty acid polyesters, PAP and SAP were synthesized through polyesterification reaction between $81 \% \mathrm{w} / \mathrm{w}$ of hydrophobic palm fatty acids (PA or SA) and $19 \% \mathrm{w} / \mathrm{w}$ of hydrophilic monomer DMPA in the presence of $0.1 \% \mathrm{w} / \mathrm{w}$ of sodium hydroxide as a catalyst. The reaction was carried out at $200 \pm 5^{\circ} \mathrm{C}$ in a three-neck reaction round bottom flask equipped with a mechanical agitator and thermometer probe and the water released was collected with a Dean-stark decanter.

The extent of polyesterification $(\mathrm{P})$ of the reaction mixture implies the percentage of the reaction completion obtained at the end of reaction. P was calculated using (1)

$$
\mathrm{P}=\frac{\mathrm{A} 0-\mathrm{At}}{\mathrm{A} 0} \times 100
$$

where $\mathrm{P}$ is the extent of the reaction; $\mathrm{A}_{0}$ is the initial a cid number taken at zero time; and $A_{t}$ is the acid number 
taken at the end of reaction.

The degree of branching of the finished polyesters can be quantified by obtaining its branching potential (BP) through (2)

$$
\mathrm{BP}=100 \times \frac{a}{b}
$$

where $a$ represents the total equivalents of multifunctional monomers having at least two reactive groups per molecule whereby $b$ is the total equivalents of all monomers.

\section{FOURIER TRANSFORM INFRARED SPECTROPHOTOMETER}

A Thermo Scientific FTIR Nicolet 6700 series FTIR spectrophotometer was used to record the spectrum of the sample. A drop of polyester was pipetted onto the diamond plate and the spectra were recorded with 32 scans ranged from 4,000 to $600 \mathrm{~cm}^{-1}$ with the resolution of 2 $\mathrm{cm}^{-1}$ at ambient temperature.

\section{PROTON NUCLEAR MAGNETIC RESONANCE SPECTROSCOPY}

Samples were dissolved in deuterated chloroform at $2 \%$ $(\mathrm{w} / \mathrm{v})$ and the proton nuclear magnetic resonance $\left({ }^{1} \mathrm{H}\right.$ NMR $)$ spectra were recorded at ambient temperature using a BRUKER 500 FTNMR spectrometer, with 32 scans recorded at a frequency of $500 \mathrm{MHz}$. Tetramethylsilane was used as internal standard at $0 \mathrm{ppm}$ and $\mathrm{CDCl}_{3}$ at $7.26 \mathrm{ppm}$.

\section{DIFFERENTIAL SCANNING CALORIMETRY}

Differential scanning calorimetry (DSC) analysis was performed using a Mettler Toledo DSC 1. About $30 \mathrm{mg}$ of sample was weighed and sealed in a $40 \mu \mathrm{L}$ aluminum sample pan. Cyclohexane was used for temperature calibration. Data was analyzed using STARe SW 13.00 software.

\section{THERMOGRAVIMETRIC ANALYSIS}

Thermogravimetric analysis (TGA) was carried out using a Perkin Elmer Thermal Analyzer (STA) 6000. About $10 \mathrm{mg}$ of sample was weighed and loaded in a ceramic sample pan. Samples were heated from 30 to $850{ }^{\circ} \mathrm{C}$ with a heating rate of $20^{\circ} \mathrm{C} / \mathrm{min}$ under a nitrogen atmosphere. Data analysis was performed using Pyris software.

\section{GEL PERMEATION CHROMATOGRAPHY}

Polyester samples were dissolved in $0.2 \% \mathrm{w} / \mathrm{v}$ of tetrahydrofuran and filtered using polytetrafluoroethylene filters with pore size of 0.45 and $0.2 \mu \mathrm{m}$. About $100 \mu \mathrm{L}$ of sample solution was then injected into a Malvern
GPC Viscotek gel permeation chromatography (GPC) instrument operated with organic GPC/SEC columns. The flow rate of $0.8 \mathrm{~mL} / \mathrm{min}$, and using $3 \times$ CLM3005-T5000 were employed in the system. Calibration was performed using polyisoprene standards. Result of number-average molecular weight $\left(\mathrm{M}_{\mathrm{n}}\right)$ was recorded.

\section{ACID NUMBER DETERMINATION}

Acid number determination of polyesters was carried out in accordance with ASTM D1980-87 (1998). Results were taken in triplicate and the average values were reported.

\section{BIOCOMPATIBILITY STUDIES}

The in vitro biocompatibility of both PAP and SAP was assessed by measuring the viability of $\mathrm{HaCaT}$ human keratinocytes, NIH/3T3 mouse fibroblasts, H2.35 mouse hepatocytes, and MDCK canine kidney cells using MTT assay. The cells were cultured in DMEM supplemented with $10 \%$ FBS medium, and 1\% penicillin-streptomycin. The cells were maintained in a humidified incubator in an atmosphere of $95 \%$ air and $5 \% \mathrm{CO}_{2}$ at $37{ }^{\circ} \mathrm{C}$. On reaching confluence, the cells were harvested and plated for subsequent assays. Cell suspensions were seeded into 96 -well plates at a density of about $1 \times 10^{4}$ cells/well and cultured for $24 \mathrm{~h}$.

After $24 \mathrm{~h}$, the culture medium was replaced with fresh medium containing either PAP, SAP or SDS sample with a series of concentrations $(3.125,6.25,12.5,25,50$, and $100 \mu \mathrm{g} / \mathrm{mL}$ ) and the cells were treated for 24,48 , and 72 h. PAP and SAP were dissolved in ethanol (vehicle) while SDS was dissolved in water. Vehicle-treated cells were served as negative control. At the end of each time point, MTT dye solution $(20 \mu \mathrm{L}, 1 \mathrm{mg} / \mathrm{mL}$ in phosphate buffer, $\mathrm{pH}$ 7.4) was added to each well and incubated for $4 \mathrm{~h}$ at $37^{\circ} \mathrm{C}$ and $5 \% \mathrm{CO}_{2}$. The medium was then removed, and formazan crystals were solubilized by gentle mixing of $100 \mu \mathrm{L}$ of DMSO. The absorbance of each well was read using microplate reader (Dynex Opsys MR 24100) at $570 \mathrm{~nm}$ and the relative cell viability was calculated using (3) by comparison with control wells.

$$
\text { Cell viability }=\frac{[A] \text { test }}{[A] \text { control }} \times 100
$$

where $[A]_{\text {test }}$ represents the absorbance of the test sample; and $[A]_{\text {control }}$ represents the absorbance of the control sample.

The average cell viability was obtained from 3 independent tests at each sample concentration. The commercial surfactants, SDS was subjected to the same test and taken as a reference of palm fatty acid polyesters aimed for comparison. 
Each of the samples was paired with vehicle control cells and cytotoxicity was rated based on the cell viability relative to control. The differences in the toxicity of each pair were compared using Student's t-test by Microsoft Excel 2016. Analysis outcomes with a confidence level of $95 \%(\mathrm{p}<0.05)$ were considered statistically significant. Mean value was calculated together with the standard deviation for each sample.

\section{RESULTS AND DISCUSSION}

\section{SYNTHESIS OF PALM FATTY ACID POLYESTERS}

A proposed mechanism of the synthesis of PAP and SAP is displayed in Figure 1. Both PAP and SAP were synthesized via polyesterification, where two moles of palm fatty acids (PA or SA) with their primary acid groups reacted with the primary alcohol groups in one mole of DMPA to form ester linkages in the branched polymeric structures. Water molecules were formed as by-products. The finished polyester structures of PAP and SAP were thus consisting of both hydrophilic and hydrophobic parts, where the hydrophilic parts formed by the DMPA monomers and the hydrophobic parts formed by the long alkyl hydrocarbon chains of the fatty acids. It was assumed that some of the secondary acid groups of DMPA might remain unreacted and left as the pendant group presented at the polymer backbone. The acid pendant groups were expected to make the polyester more hydrophilic.

From Figure 1, both general chemical structures of PAP and SAP were similar, where the only difference was the chain length of the alkyl hydrocarbon located at both ends of the chain, in which PAP has a carbon chain length of 15 whereas SAP has a carbon chain length of 17.<smiles>[14CH3]C(=O)O</smiles><smiles>CC(=O)OCC(C)C(CC(C)(C)C)C(=O)O</smiles><smiles>[R]O[Na]</smiles><smiles>[R]OCC(COC(=O)C(C)(C)C)(COC(=O)C(C)(C)C)C(=O)O</smiles>

FIGURE 1. A schematic diagram of the chemical synthesis of PAP and SAP

FTIR ANALYSIS OF PAP AND SAP

Both FTIR spectra of PAP and SAP show the $-\mathrm{C}=\mathrm{O}$ stretching correspondences to the ester linkage at 1742$1737 \mathrm{~cm}^{-1}$ (Figure 2). Generally, the absorption peaks are found to be identical in PAP and SAP, indicating both polyesters have very similar chemical structures, including
-OH stretching appears as a broad absorption band at $3498-3440 \mathrm{~cm}^{-1}$, C-H stretching of methane group (2949$2921 \mathrm{~cm}^{-1}$ ), C-H stretching of methylene group (2852$\left.2849 \mathrm{~cm}^{-1}\right)$, C-H bending of methylene group (1467-1377 $\left.\mathrm{cm}^{-1}\right)$, C-O-C stretching (1237-1012 $\left.\mathrm{cm}^{-1}\right)$, and lastly C-H out-of-plane stretching $\left(722-720 \mathrm{~cm}^{-1}\right)$.

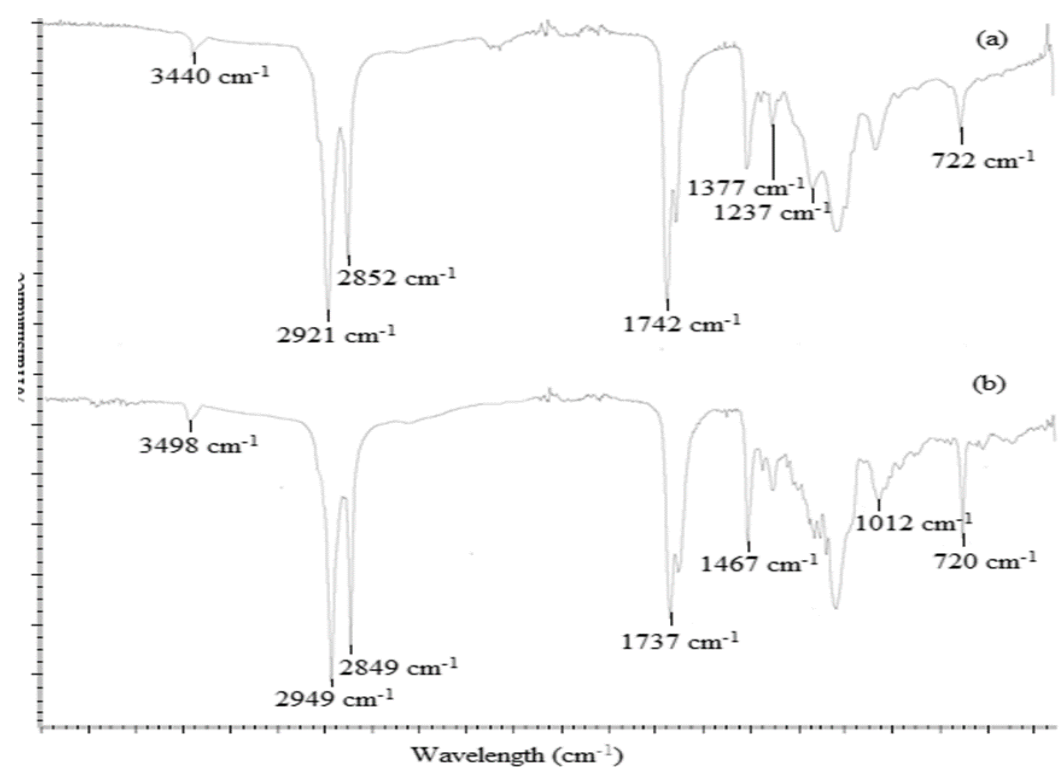

FIGURE 2. FTIR spectra of palm fatty acid polyesters, (a) PAP and (b) SAP 
${ }^{1} \mathrm{H}$ NMR ANALYSIS OF PAP AND SAP

The chemical structures of PAP and SAP were further examined using ${ }^{1} \mathrm{H}-\mathrm{NMR}$ as illustrated in Figure 3. Both PAP and SAP were found to have identical chemical shift values corresponding to the protons available at the backbone of the chemical structures. This further supports the similarity of the chemical structure of PAP and SAP as observed in FTIR spectrum. With reference to Figure 3 , the peak at $0.9 \mathrm{ppm}$ represents the terminal methyl proton, peaks at $1.3 \mathrm{ppm}$ corresponds to the methylene proton, peak at $1.5-2.0 \mathrm{ppm}$ refers to the methine proton, peak at 2.0-2.3 ppm indicates the $-\mathrm{CH}_{2}$ - adjacent to the carbonyl group of the ester group, and the peak available in between 4.0-4.2 ppm reflects to the methylene proton neighboring to the hydroxyl group.

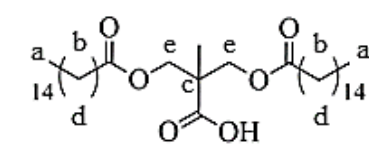

(a)
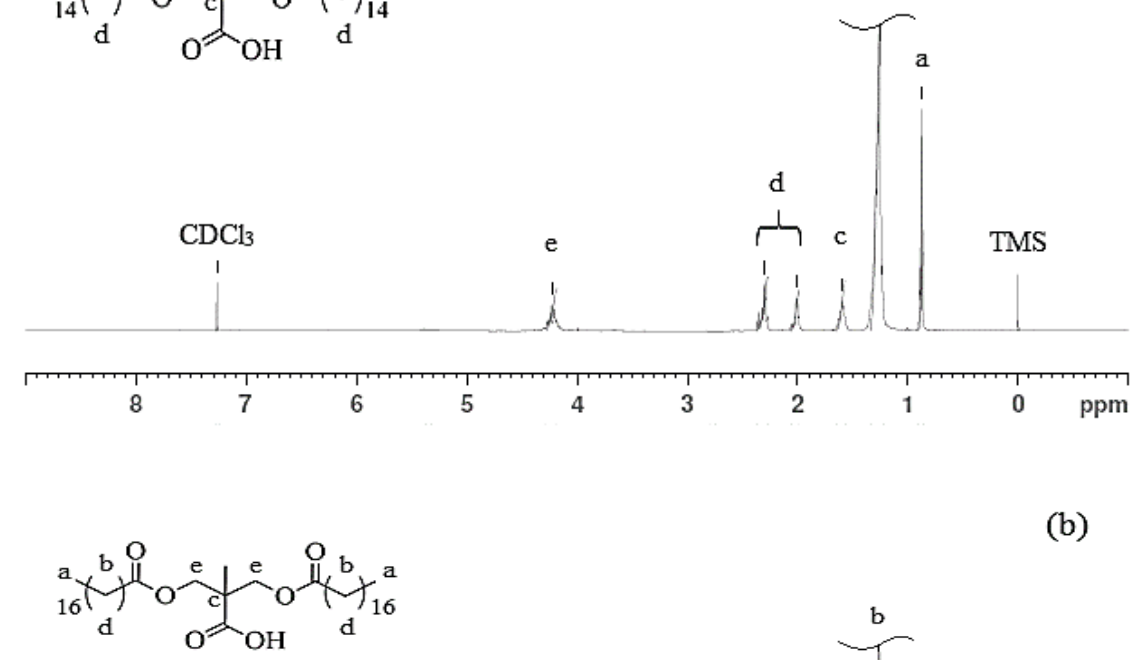

(b)

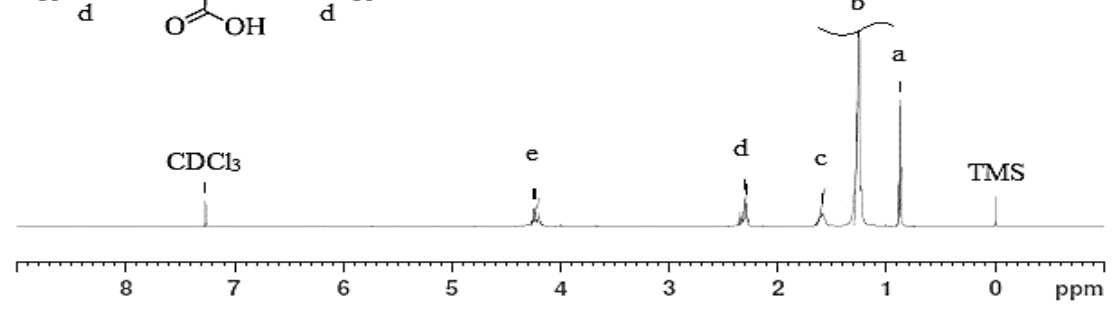

FIGURE 3. ${ }^{1} \mathrm{H}-\mathrm{NMR}$ spectra of palm fatty acid polyesters, (a) PAP and (b) SAP

\section{PROPERTIES OF PALM FATTY ACID POLYESTERS}

The physiochemical properties of both PAP and SAP are listed in Table 1. From Table 1, PAP appears to be in liquid state, but the SAP is semisolid at room temperature due to the natural solid nature of palm stearin. The progression of the synthesis reaction was reflected by $\mathrm{P}$ value expressed in terms of percentage. Both PAP and SAP demonstrated partial completion of the reaction, suggesting that there were nearly $21-22 \%$ of reactants remain unreacted and this was evidenced by the high acid values recorded.

The glass transition temperature $\left(T_{q}\right)$ distinguishes PAP and SAP by using DSC analysis under the performance of the reappearance of endothermic peaks following by heating, cooling and reheating cycles. As shown in Table $1, T_{g}$ of PAP is $1.8^{\circ} \mathrm{C}$ whereas the $T_{g}$ of SAP is $31.9^{\circ} \mathrm{C}$. $T_{g}$ could be affected by the chain mobility of the chemical structure. $T_{g}$ of a compound is dependent on the flexibility of the main chain structure, the pendant side group as well as the main chain polarity, which can be expressed as the degree of freedom of the overall chemical structure. Theoretically, a higher degree of freedom associated with a greater extend on the rotation of the chain segments, which leading to a higher chain flexibility due to higher segmental mobility along the backbone of the structure, eventually results in lower $T_{g}$ of the compound (Jadhav et al. 2014). Basically, both PAP and SAP consist 
of DMPA in their main chains whereby this bulky group increases the intermolecular cohesion of the overall structure. SAP has a higher $T_{g}$ than PAP as it has a longer alkyl chain with extra two units of methylene groups. A slightly higher branching potential of SAP (34\%) than PAP $(31 \%)$ could also contribute to the increase in chain rigidity and higher $T_{g}$ value.

TABLE 1. Physiochemical properties of PAP and SAP

\begin{tabular}{ccc}
\hline Property & PAP & SAP \\
\hline Physical appearance & liquid & semisolid \\
Percentage of reaction completion, P & 78 \\
Acid value (mg KOH/g) & 79 & 85.3 \\
Branching potential, BP $(\%)$ & 80.1 & 34 \\
Glass transition temperature, $\mathrm{T}_{\mathrm{g}}\left({ }^{\circ} \mathrm{C}\right)$ & 31 & 31.9 \\
Number-average molecular weight, & 1.8 & 972 \\
$\mathrm{M}_{\mathrm{n}}(\mathrm{g} / \mathrm{mol})$ & 1031 & \\
\hline
\end{tabular}

\section{TGA ANALYSIS OF PAP AND SAP}

Figure 4 displays the TGA thermographs of PAP and SAP. The thermal derivatives showed that thermal decompositions of PAP and SAP were similar involving two-stage processes occurring above $200{ }^{\circ} \mathrm{C}$ indicating high thermal stability for both products. For PAP, the weight loss was $56.7 \%$ occurred at $335{ }^{\circ} \mathrm{C}$ and $31.6 \%$ at $362^{\circ} \mathrm{C}$. Similarly, a slightly higher decomposition temperature at 339 and $366{ }^{\circ} \mathrm{C}$ with weight loss of 46.2 and $17.9 \%$, respectively, was observed for SAP.
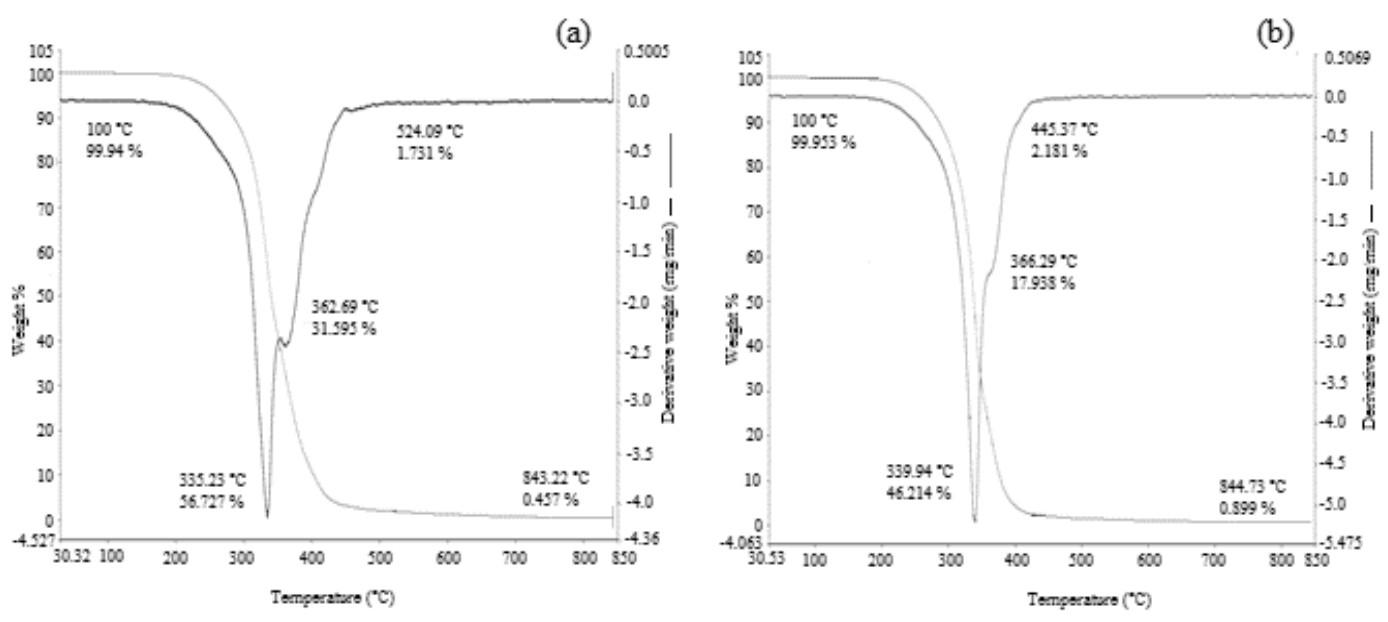

FIGURE 4. TGA thermograms of palm fatty acid polyesters, (a) PAP and (b) SAP 


\section{in vitro BIOCOMPATIBILITY STUDIES}

The cytotoxic activity of palm fatty acid polyesters against human keratinocytes (HaCaT), mouse fibroblasts (3T3), mouse hepatocytes (H2.35), and canine kidney cells (MDCK) was evaluated using MTT assay. Both PAP and SAP could functionalize as a polymeric surfactant. Hence, SDS was chosen to serve as the commercially available reference. SDS is an anionic surfactant used in many cleaning and hygiene products. Recently, the effectiveness of SDS in proteins removal using urea-SDS protein denaturation mechanism to produce deproteinized natural rubber (DPNR) latex was reported (Chaikumpollert et al. 2012; Kawahara et al. 2004; Yamamoto et al. 2008).

Initially, $\mathrm{HaCaT}$ cells or keratinocytes was chosen as the preliminary test for cytotoxicity. Keratinocytes are the predominant cell type in the epidermis and thus are affected first by toxic substances through direct contact. The viability of $\mathrm{HaCaT}$ cells following exposure to PAP and SAP, as well as SDS was compared with the viability of vehicle control (V.Ctrl) cells as shown in Figure 5(a)-5(c). Cytotoxicity was rated based on the cell viability relative to controls and pursuant to ISO 10993-5, percentages of cell viability above $80 \%$ are considered as non-cytotoxicity; within $80-60 \%$ as weak; $60-40 \%$ as moderate and below $40 \%$ as strong cytotoxicity (LopezGarcia et al. 2014). From Figure 5(a)-5(b), it is clearly seen that the percentages of cell viability in both palm fatty acid polyesters were well above $80 \%$ and thus PAP and SAP were considered to be non-toxic towards $\mathrm{HaCaT}$ cell. This indicates that PAP and SAP are safe in short and prolonged skin contact. Nevertheless, SDS exhibited both time and dose-dependent toxicity, particularly at concentrations of 50 and $100 \mu \mathrm{g} / \mathrm{mL}$, with the difference in mean was significant where $\mathrm{p}<0.05$ as depicted in Figure 5(c). Robinson et al. (2010) has reported the irritant properties of SDS, where the concentration limit of $1 \%$ is applied in products intended for prolonged skin contact. Furthermore, SDS might even worsen skin problems in individuals with chronic skin hypersensitivity (Marrakchi \& Maibach 2006). Therefore, both PAP and SAP have a very high biocompatibility and safe for topical application.

(a)

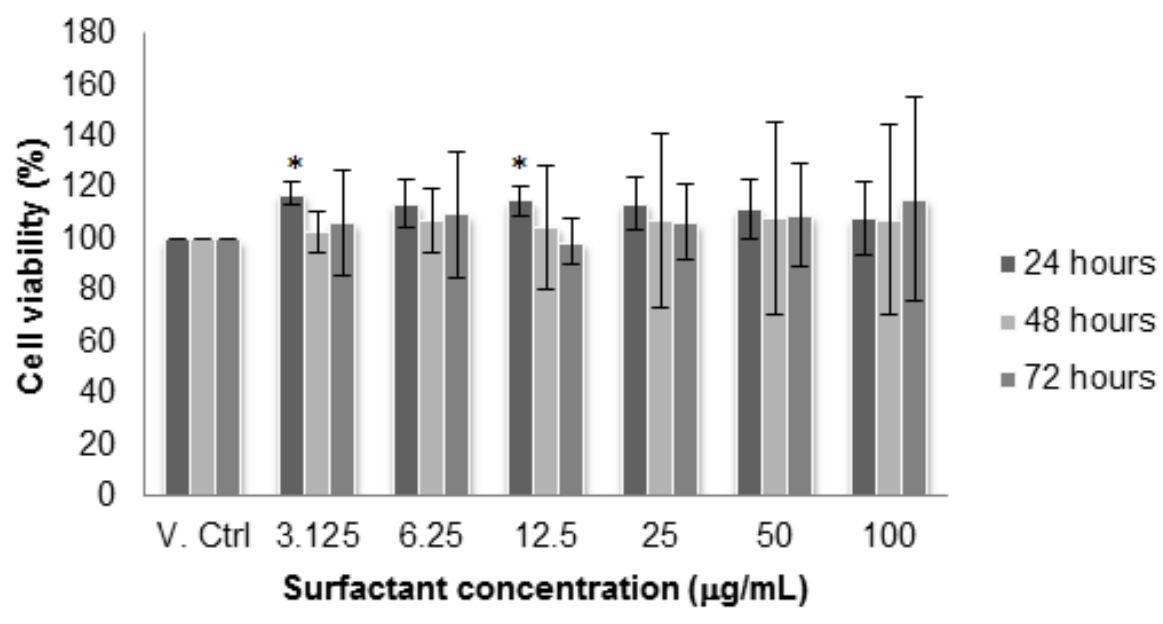

(b)

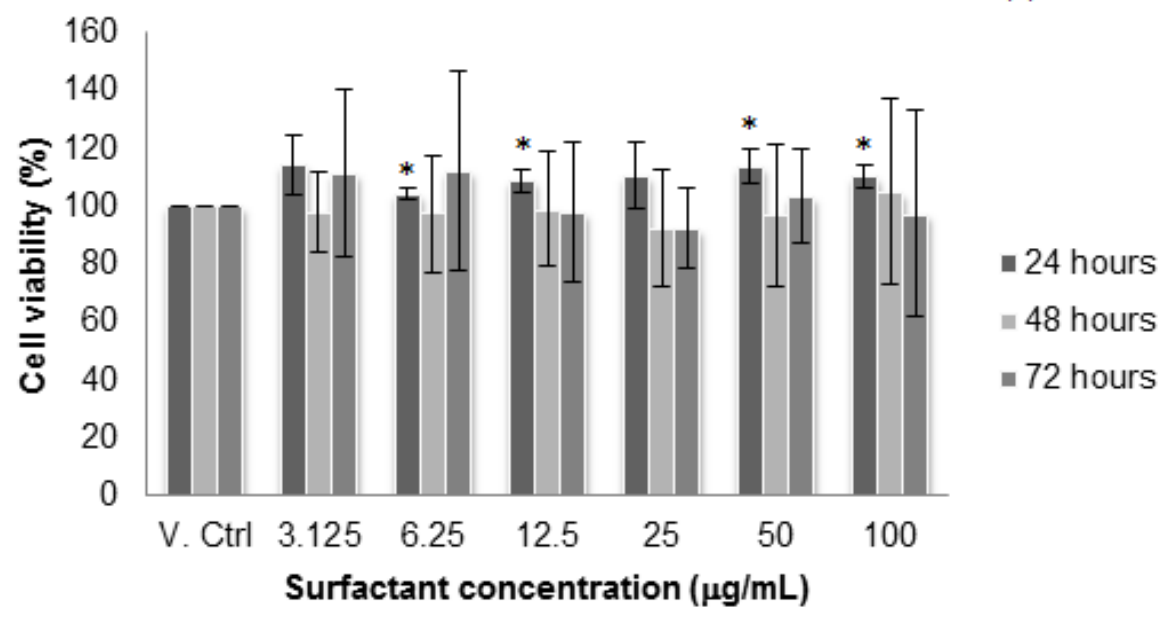




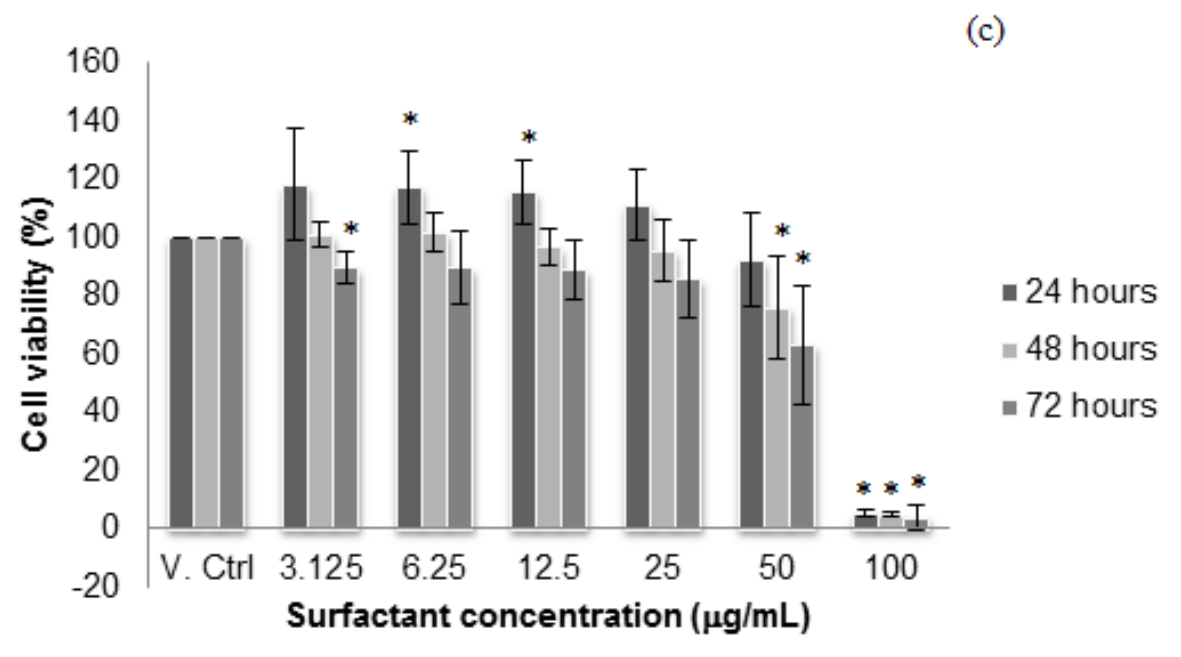

FIGURE 5. Effect of palm fatty acid polyesters (a) PAS; (b) SAS; and reference commercial surfactant (c) SDS on the viability of HaCaT cells after treatment of 24, 48, and $72 \mathrm{~h}$. Cell viability was presented as percentage of absorbance with $100 \%$ representing vehicle control (V.Ctrl) cells. Data was expressed in mean $\pm \mathrm{SD}(\mathrm{n}=3)$. The symbol $*$ denotes significant differences between control and treatment groups at $\mathrm{p}<0.05$

in vitro cytotoxicity test of the polyesters was also performed on cultured fibroblasts (3T3). The MTT results of synthesized polyesters and commercial surfactant are depicted in Figure 6(a)-6(c). It was found that PAP (Figure 6(a)) has the cell viability above $80 \%$ and thus considered as non-toxic. However, SAP (Figure 6(b)) demonstrated a significant decline in $3 \mathrm{~T} 3$ cell viability following exposure at $100 \mu \mathrm{g} / \mathrm{mL}$ of polyester concentration. This suggests that SAP exhibits moderate low cytotoxicity on the fibroblasts, at $100 \mu \mathrm{g} / \mathrm{mL}$, with the cell viability remaining at $50.4 \%$ after $72 \mathrm{~h}$ exposure. The results of the MTT assay for SDS (Figure 6(c)) was very similar to the previous results in $\mathrm{HaCaT}$ as displayed in Figure 5(c). Generally, the MTT assay showed that the palm fatty acid polyesters synthesized in the present study have good biocompatibility with generalized insignificant or potential low toxicity to cells. Henceforth, it is recommended that the concentration of polyesters used for pharmaceutical applications should be limited to less than $100 \mu \mathrm{g} / \mathrm{mL}$, particularly in the case of SAP.

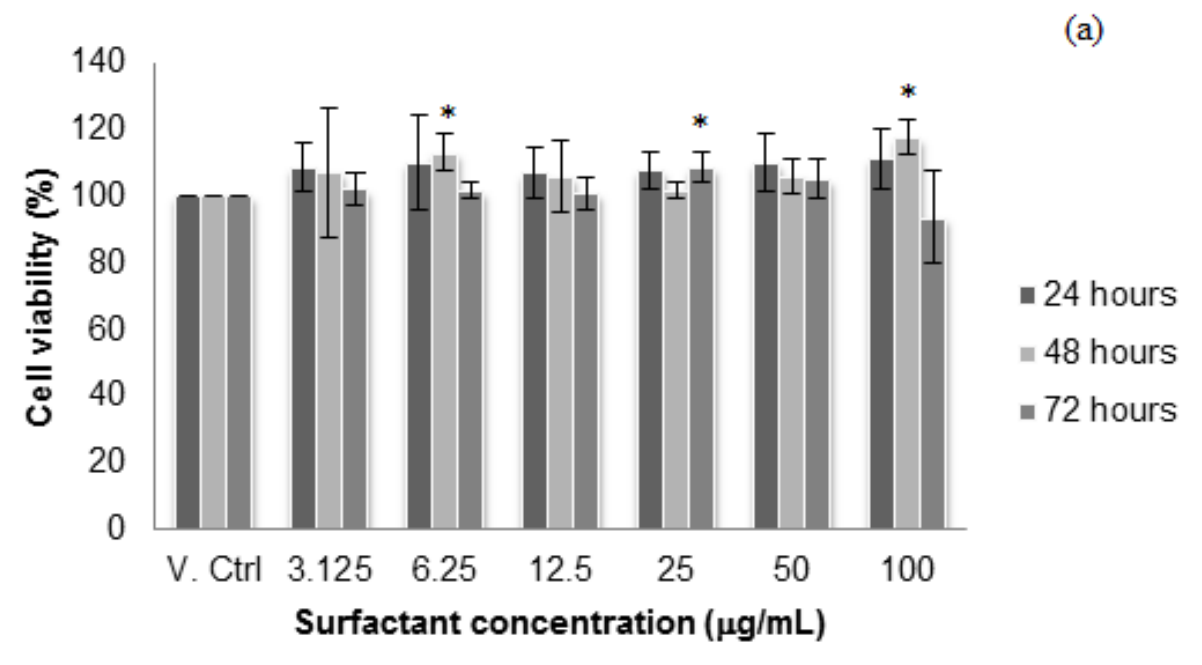



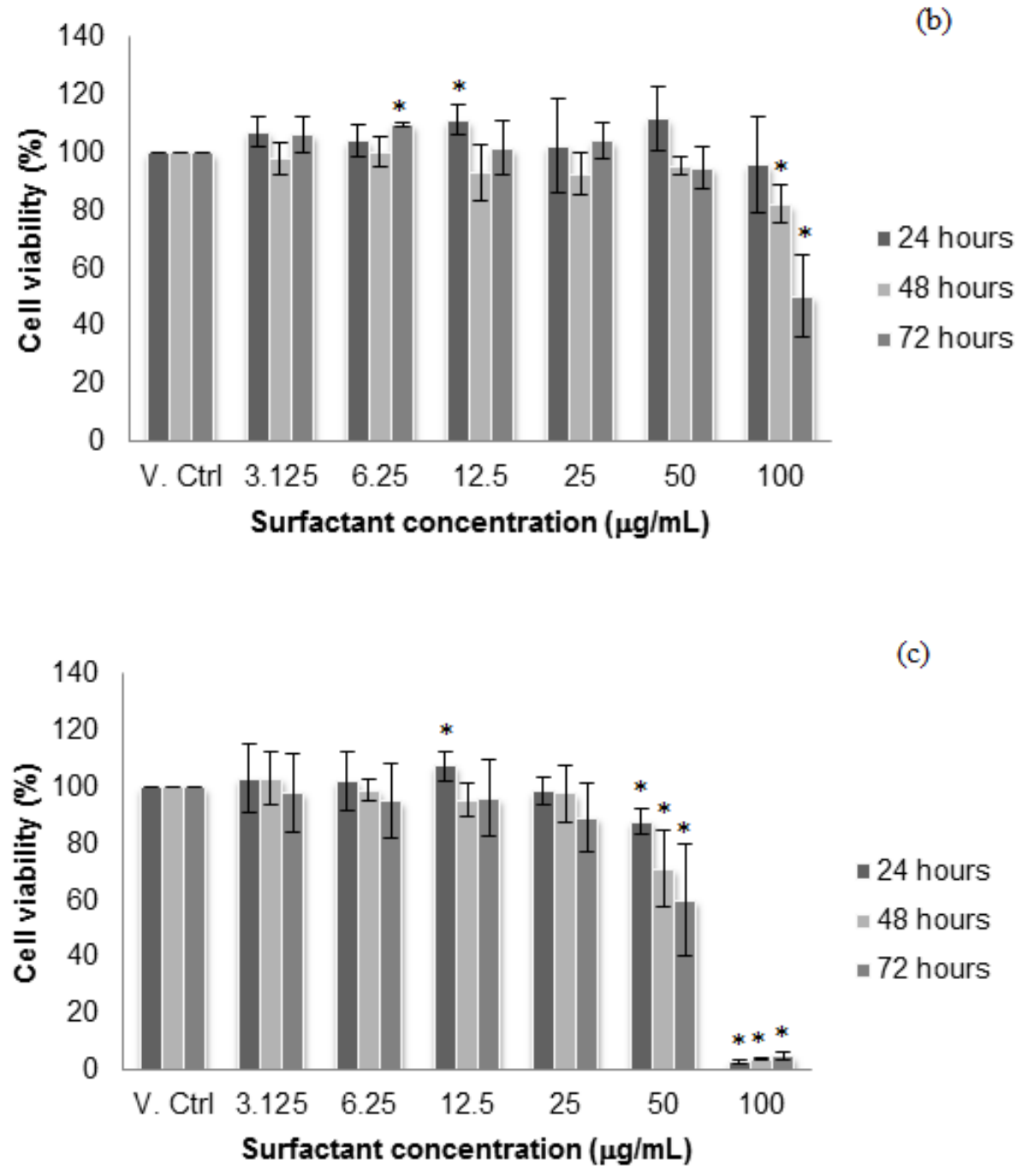

FIGURE 6. Effect of palm fatty acid polyesters (a) PAP; (b) SAP; and reference commercial surfactant (c) SDS on the viability of 3 T3 cells after treatment of 24, 48, and $72 \mathrm{~h}$. Cell viability was presented as percentage of absorbance with $100 \%$ representing vehicle control (V.Ctrl) cells. Data was expressed in mean $\pm \mathrm{SD}(\mathrm{n}=3)$. The symbol * denotes significant differences between control and treatment groups at $\mathrm{p}<0.05$

It is a known fact that the liver is the vital organ in the human body which has a recognized function in xenobiotic metabolism in all vertebrates (Abdel-Mishi \& Bloomston 2010). Judging from these, hepatocytes (H2.35) were used to determine the hepatic toxicity of palm fatty acid polyesters synthesized. Interestingly, both PAP and SAP also established their high biocompatibility by having high percentages of cell viability above $80 \%$ as displayed in Figure 7(a)-7(b). As for the commercial surfactant shown in Figure 7(c), SDS showed a significant toxicity particularly at high concentration, in both timeand dose-dependent manners. The acquired data indicate that these palm fatty acid polyesters were non-toxic to liver cells and are proved to be safe for oral consumption. Thus, PAP and SAP show a high potential to be utilized in oral drug formulations. 

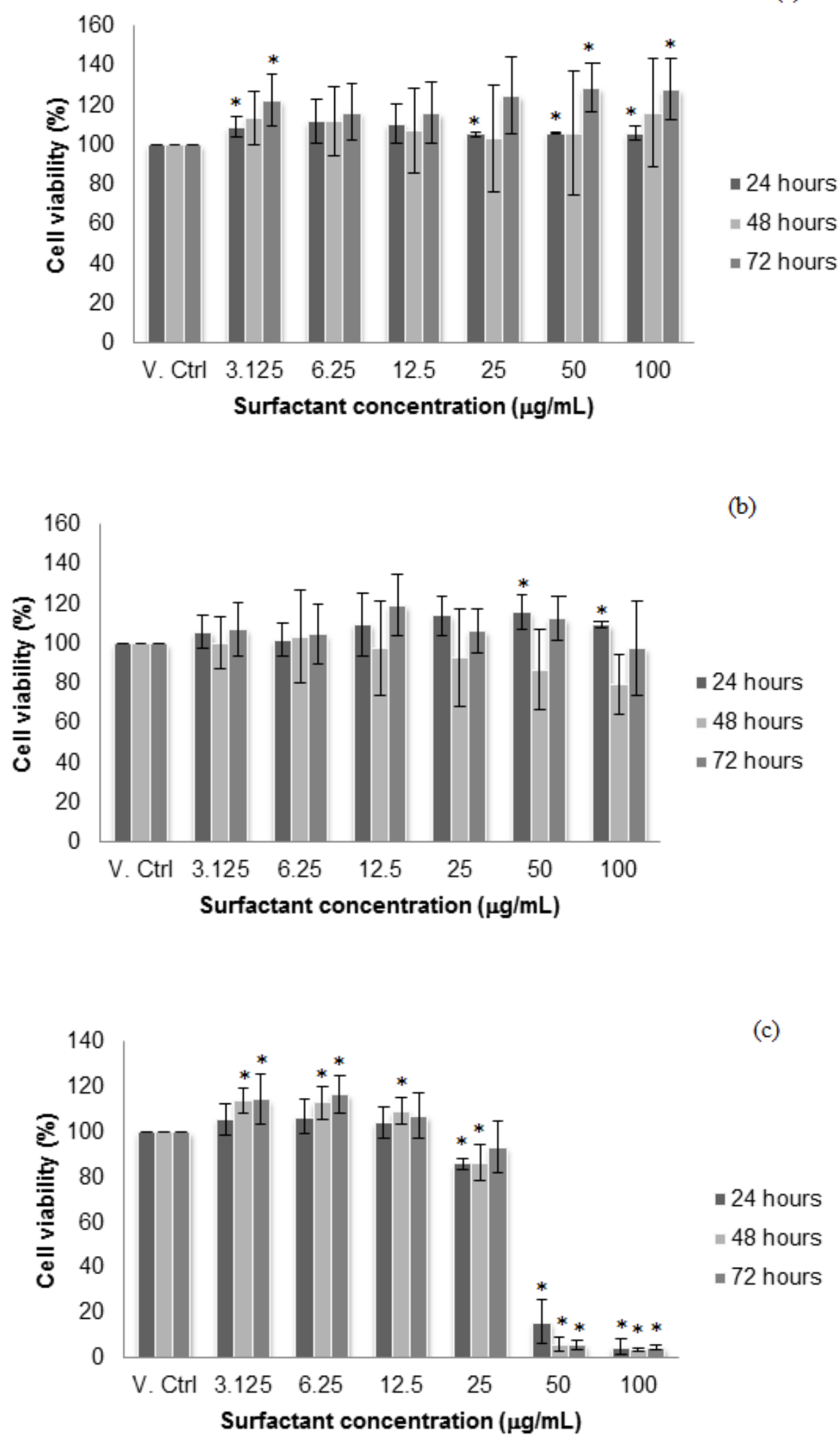

FIGURE 7. Effect of palm fatty acid polyesters (a) PAP; (b) SAP; and reference commercial surfactant (c) SDS on the viability of $\mathrm{H} 2.35$ cells after treatment of 24, 48 , and $72 \mathrm{~h}$. Cell viability was presented as percentage of absorbance with $100 \%$ representing vehicle control (V.Ctrl) cells. Data was expressed in mean $\pm \mathrm{SD}(\mathrm{n}=3)$. The symbol * denotes significant differences between control and treatment groups at $\mathrm{p}<0.05$ 
Moreover, canine kidney cells MDCK (NBL-2) were subjected to this study and used as a renal model to screen the nephrotoxicity of palm fatty acid polyesters since kidney is susceptible to xenobiotics due to its high blood supply and its ability to concentrate toxins. As displayed in Figure 8(a)-8(b), exposing MDCK cells to PAP and SAP were found to be non-toxic. Polyesters synthesized exposing to MDCK cells did not affect cell viability within $72 \mathrm{~h}$ exposure and $3.125-100 \mu \mathrm{g} / \mathrm{mL}$ of concentrations. Nevertheless, SDS (Figure 8(c)) showed significant toxicity at high concentration.
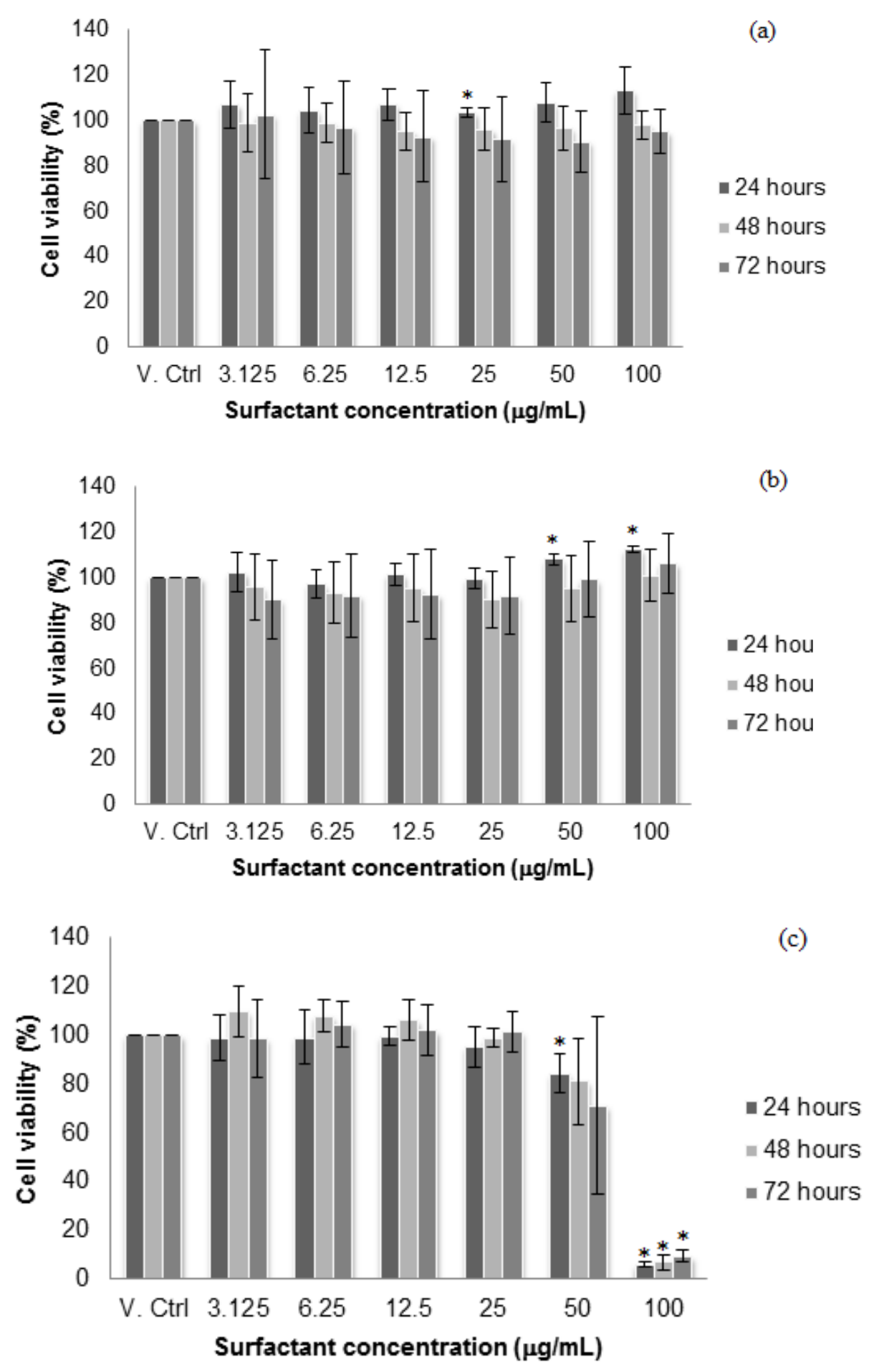

FIGURE 8. Effect of palm fatty acid polyesters (a) PAP; (b) SAP; and reference commercial surfactant (c) SDS on the viability of MDCK (NBL-2) cells after treatment of 24, 48, and $72 \mathrm{~h}$. Cell viability was presented as percentage of absorbance with $100 \%$ representing vehicle control (V.Ctrl) cells. Data was expressed in mean $\pm \mathrm{SD}(\mathrm{n}=3)$. The symbol * denotes significant differences between control and treatment groups at $\mathrm{p}<0.05$ 
Taken together, these findings highly recommend consideration of the novel, biocompatible palm fatty acid polyesters as potential additives for pharmaceutical formulations and medical device applications. Since both PAP and SAP contain ester linkages, it was expected that they are also biodegradable where they can be degraded in the body by simple hydrolysis of ester backbone to non-harmful and non-toxic components. The degradation products are either excreted through kidneys or eliminated in form of carbon dioxide and water via some established biochemical pathways. Furthermore, these synthetic polymers can be prepared with chemical structures tailored to optimize physical properties of the biomedical materials, with well-defined purities and compositions superior to those attainable when using natural polymers.

\section{CONCLUSION}

Palm fatty acid polyesters have been successfully synthesized from natural-sourced starting materials as aliphatic polyesters. The MTT assay showed that the palm fatty acid polyesters synthesized in the present study have high biocompatibility and non-toxic to many cell types. This implies that both PAP and SAP are environmentally friendly compounds. It is recommended that less than $100 \mu \mathrm{g} / \mathrm{mL}$ of SAP should be used for pharmaceutical applications. Hence, they could be considered as biocompatible green materials for medical devices and orally safe compounds for pharmaceutical and nutraceutical formulations.

\section{ACKNOWLEDGEMENTS}

The authors would like to appreciate the financial support from Malaysian Rubber Board (grant number: S17STL0663).

\section{REFERENCES}

Abdel-Misih, S.R. \& Bloomston, M. 2010. Liver anatomy. Surgical Clinics 90(4): 643-653.

Ang, D.T.C. \& Gan, S.N. 2012. Development of palm oil-based alkyds as UV curable coatings. Pigment \& Resin Technology 41(5): 302-310.

Babu, R.P., O'connor, K. \& Seeram, R. 2013. Current progress on bio-based polymers and their future trends. Progress in Biomaterials 2: 8

Bakand, S., Winder, C., Khalil, C. \& Hayes, A. 2006. An experimental in vitro model for dynamic direct exposure of human cells to airborne contaminants. Toxicology Letters 165(1): 1-10.

Bakand, S., Winder, C., Khalil, C. \& Hayes, A. 2005. Toxicity assessment of industrial chemicals and airborne contaminants: Transition from in vivo to in vitro test methods: A review. Inhalation Toxicology 17(13): 775-787.
Chaikumpollert, O., Yamamoto, Y., Suchiva, K. \& Kawahara, S. 2012. Protein-free natural rubber. Colloid and Polymer Science 290(4): 331-338.

De, S., Malik, S., Ghosh, A., Saha, R. \& Saha, B. 2015. A review on natural surfactants. RSC Advances 5(81): 65757-65767.

Garrison, T.F., Murawski, A. \& Quirino, R.L. 2016. Bio-based polymers with potential for biodegradability. Polymers 8(7): 262.

Hoh, A. \& Maier, K. 1993. Comparative Cytotoxicity Test with Human Keratinocytes, HaCaT Cells, and Skin Fibroblasts to Investigate Skin-Irritating Substances: Cell and Tissue Culture Models in Dermatological Research. Berlin: Springer. pp. 341-347.

Jadhav, N.R., Gaikwad, V.L., Nair, K.J. \& Kadam, H.M. 2014. Glass transition temperature: Basics and application in pharmaceutical sector. Asian Journal of Pharmaceutics 3(2): 82-89.

Kawahara, S., Klinklai, W., Kuroda, H. \& Isono, Y. 2004. Removal of proteins from natural rubber with urea. Polymers for Advanced Technologies 15(4): 181-184.

Lee, J.K., Kim, D.B., Kim, J.I. \& Kim, P.Y. 2000. In vitro cytotoxicity tests on cultured human skin fibroblasts to predict skin irritation potential of surfactants. Toxicology in Vitro 14(4): 345-349.

Lee, S.Y. \& Gan, S.N. 2013. The adhesion properties of natural rubber pressure-sensitive adhesives using palm kernel oil-based alkyd resins as a tackifier. Composite Interfaces 20(3): 177-188.

Lee, S.Y., Gan, S.N., Hassan, A., Tan, I.K.P., Terakawa, K. \& Ichikawa, N. 2010. Reactions of palm oil-based mclPHAs with epoxidized natural rubber. Journal of Applied Polymer Science 115(4): 2039-2043.

López-García, J., Lehocký, M., Humpolíček, P. \& Sáha, P. 2014. HaCaT keratinocytes response on antimicrobial atelocollagen substrates: Extent of cytotoxicity, cell viability and proliferation. Journal of Functional Biomaterials 5(2): 43-57.

Marrakchi, S. \& Maibach, H.I. 2006. Sodium lauryl sulfateinduced irritation in the human face: Regional and agerelated differences. Skin Pharmacology and Physiology 19(3): 177-180.

Riss, T.L., Moravec, R.A., Niles, A.L., Duellman, S., Benink, H.A., Worzella, T.J. \& Minor, L. 2016. Assay guidance manual. In Cell Viability Assays [Internet], edited by Markossian, S., Sittampalam, G.S., Grossman, A., Brimacombe, K., Arkin, M., Auld, D., Austin, C.P., Baell, J., Caaveiro, J.M.M., Chung, T.D.Y., Coussens, N.P., Dahlin, J.L., Devanaryan, V., Foley, T.L., Glicksman, M., Hall, M.D., Haas, J.V., Hoare, S.R.J., Inglese, J., Iversen, P.W., Kahl, S.D., Kales, S.C., Kirshner, S., Lal-Nag, M., Li, Z., McGee, J., McManus, O., Riss, T., Saradjian, P., Trask Jr., O.J., Weidner, J.R., Wildey, M.J., Xia, M. \& Xu, X. Bethesda (MD): Eli Lilly \& Company and the National Center for Advancing Translational Sciences.

Robinson, V.C., Bergfeld, W.F., Belsito, D.V., Hill, R.A., Klaassen, C.D., Marks, J.G., Shank, R.C., Slaga, T.J., Snyder, P.W. \& Andersen, F.A. 2010. Final report of the amended safety assessment of sodium laureth sulfate and related 
salts of sulfated ethoxylated alcohols. International Journal of Toxicology 29(4 Suppl): 151S-161S.

Yamamoto, Y., Nghia, P.T., Klinklai, W., Saito, T. \& Kawahara, S. 2008. Removal of proteins from natural rubber with urea and its application to continuous processes. Journal of Applied Polymer Science 107(4): 2329-2332.

Yvonne Tze Qzian Ling, Yi Xin Heng, Desmond Teck Chye Ang \& Seng Neon Gan

Department of Chemistry

Faculty of Science, University of Malaya Jalan Universiti, 50603 Kuala Lumpur, Federal Territory Malaysia

Yvonne Tze Qzian Ling, Yi Xin Heng \& Siang Yin Lee* Latex Science and Technology Unit (USTL)

Technology and Engineering Division (BTK)

RRIM Sungai Buloh Research Station

Malaysian Rubber Board (MRB)

47000 Sungai Buloh, Selangor Darul Ehsan

Malaysia
Yiing Jye Yap

Jeffrey Cheah School of Medicine and Health Science

Monash University Malaysia, Bandar Sunway

47500 Selangor Darul Ehsan

Malaysia

Rhun Yian Koh

School of Health Sciences

Division of Applied Biomedical Science and Biotechnology International Medical University

No.126, Jalan Jalil Perkasa 19, Bukit Jalil

57000 Kuala Lumpur, Federal Territory

Malaysia

Chin Hua Chia

Material Science Program

Faculty of Science and Technology

Universiti Kebangsaan Malaysia

43600 UKM Bangi, Selangor Darul Ehsan

Malaysia

*Corresponding author; email: leesiangyin@lgm.gov.my

Received: 15 May 2019

Accepted: 21 July 2020 